\title{
Hypodermoclysis: a literature review to assist in clinical practice
}

\author{
Hipodermóclise: revisão de literatura para auxiliar a prática clínica
}

\author{
Vanessa Galuppo Bruno ${ }^{1}$
}

\begin{abstract}
The aim of this study was to analyze the information available in the literature about the drugs that can be administered through hypodermoclysis and the resulting impact that this information may have on the routine of the pharmacist working at a hospital. The study was based on a review of the literature. The results showed positive points of the procedure, but little specific information about medications such as routes of administration, standard dilutions, optimal doses, etc. Thus, it was possible to verify that there is no definite information as to the correct way to administer the drugs in this route, even though this is an effective and safe option, according to the literature. The lack of information has a negative impact on the support provided by the pharmacist to the nursing staff to ensure that the drug actually reaches its therapeutic goals safely.
\end{abstract}

Keywords: Hypodermoclysis; Palliative care; Infusions, subcutaneous

\section{RESUMO}

0 objetivo desse trabalho, foi analisar, na literatura, as informações disponíveis sobre os medicamentos que podem ser administrados através da hipodermóclise e o impacto que a informação pode acarretar na rotina do farmacêutico dentro de uma unidade hospitalar. 0 estudo foi baseado em uma revisão de literatura. Os resultados encontrados, demonstraram pontos positivos do procedimento, porém foram localizadas poucas informações específicas sobre medicamentos, como métodos de administração, padrões de diluição, dose ideal etc. Dessa forma, foi possível verificar que não há informações definitivas quanto ao modo mais correto de se administrar as drogas por essa via, mesmo sendo esta uma opção eficaz e segura, conforme a literatura. A falta de informação impacta negativamente no suporte realizado pelo farmacêutico à equipe de enfermagem para garantir que 0 medicamento realmente alcance seus objetivos terapêuticos com segurança.

Descritores: Hipodermóclise; Cuidados paliativos; Infusões subcutâneas

\section{INTRODUCTION}

Hypodermoclysis is also known as the administration of fluids by the subcutaneous route. It is an ancient practice and was first reported in 1913, but because of the adverse events resulting from its inadequate use, such as the use of hypertonic solutions, the practice was abandoned. ${ }^{(1-4)}$

It has been used in patients who present with diagnoses of moderate dehydration caused by severe dysphagia, dementia, intestinal obstruction due to neoplasms, and somnolence. There is also the possibility of administering medications to those patients who have no conditions for a peripheral venous access puncture..$^{(1,2,4-9)}$

Hypodermoclysis is also described as a simple practice and less expensive than the other techniques. ${ }^{(10)}$

The medications and fluids given by hypodermoclysis are absorbed by means of capillary diffusion mechanisms. Patient edema and hematomas may hinder treatment. ${ }^{(11,12)}$ The pharmacokinetics are similar to those of medications administered by intramuscular route, but display a prolonged time of action, besides better tolerability for

'Hospital Israelita Albert Einstein, São Paulo, SP, Brazil.

Corresponding author: Vanessa Galuppo Bruno - Rua Coronel Lisboa, 139 - Vila Mariana - CEP: 04020-040 - São Paulo, SP, Brazil - Phone: (55 11) 2151-7240 - E-mail: vanessagb@einstein.br

Received on: Aug 1, 2012 - Accepted on: Dec 1, 2013

DOI: 10.1590/S1679-45082015RW2572 
those medications with a $\mathrm{pH}$ close to neutral and that are hydrosoluble. ${ }^{(11)}$

In order to facilitate administration of medications by hypodermoclysis, some literature suggests the use of hyaluronidase, as this is an enzyme that decomposes the hyaluronic acid present in the tissue, leading to decreased viscosity and thus increasing the rate of absorption of the drugs given. ${ }^{(3)}$

There are locations (puncture sites) that are more appropriate for therapy, such as the deltoid region, anterior chest region, scapular region, abdominal regional, and anterior and lateral sides of the thighs. (Figure 1)
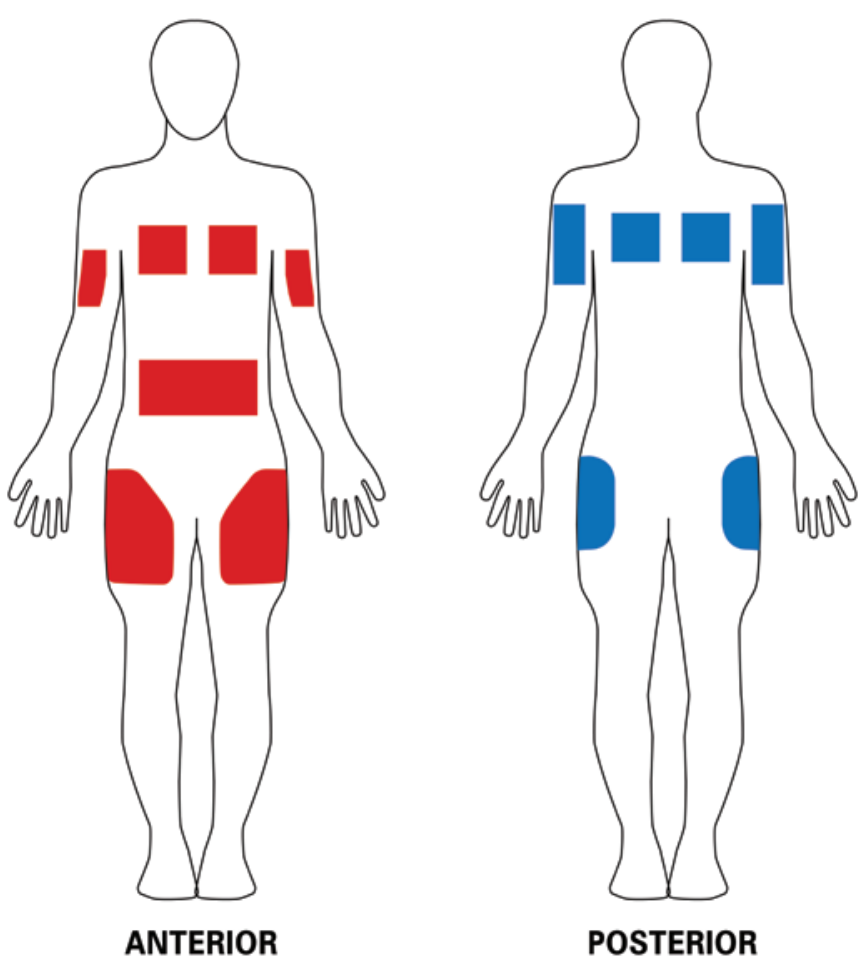

Figure 1. Puncture sites

In Brazil, this technique has been gaining acceptance for use in patients in Palliative Care or in those who are very old or debilitated.

Subcutaneous therapy does not cover only replacement fluids, but also medications that have been prescribed through this route, such as antimicrobials and analgesics, among others.

Some of these medications have no description on the packet insert as to the possibility of being given by this technique; therefore, when prescribed, we consider their use as "off-label".
For professional prescribers, in general, indication of route of administration is based on the international literature or on one's own clinical experience, which is not reported in official articles.

For the local Pharmacy, the lack of reliable information generates certain difficulties when evaluating a medical prescription, as well as in instructing the nursing team as to the necessary care for use of the prescribed drug, since each medication has its own exclusive characteristics, such as $\mathrm{pH}$, stability, besides appropriate dilution and diluent volumes.

Since there is little information in literature on this topic, the interest arose to analyze, by means of this study, what national and international literature has become available on hypodermoclysis and to what extent this information may be valuable to the pharmacist, since this professional is the one responsible for the medications within a hospital.

\section{METHODS}

This is a bibliographic research, with review of literature. Books and manuals on Palliative Care were consulted, and searches conducted for articles and guidelines in the databases Scientific Electronic Library Online (SciELO), MEDLINE, and Google Scholar. The keywords used were "hypodermolysis", "Palliative Care", and "subcutaneous route", published in Portuguese and English, within a timeframe that included the years 1999 to 2012 .

The articles were analyzed according to the objective proposed so that the papers that had information related to the use of medications and the method of their use, hydratrating solutions $(0.9 \%$ sodium chloride, $0.45 \%$ sodium chloride, and $5 \%$ glucose), besides the advantages and disadvantages of the technique and possible adverse reactions.

Many of the studies and guidelines found in preparing this study were international. Even so, they do not offer a large amount of information as to the topic, especially as to the use of drugs.

The information was tabulated on an electronic spreadsheet (EXCEL) and presented in the form of charts and tables.

To prepare the chart related to compatibilities, the Micromedex ${ }^{\circledR}$ electronic database was used as a tool.

Chart 1 presents information on the medications cited in the articles. 
Chart 1. Table of medications most often used by subcutaneous route

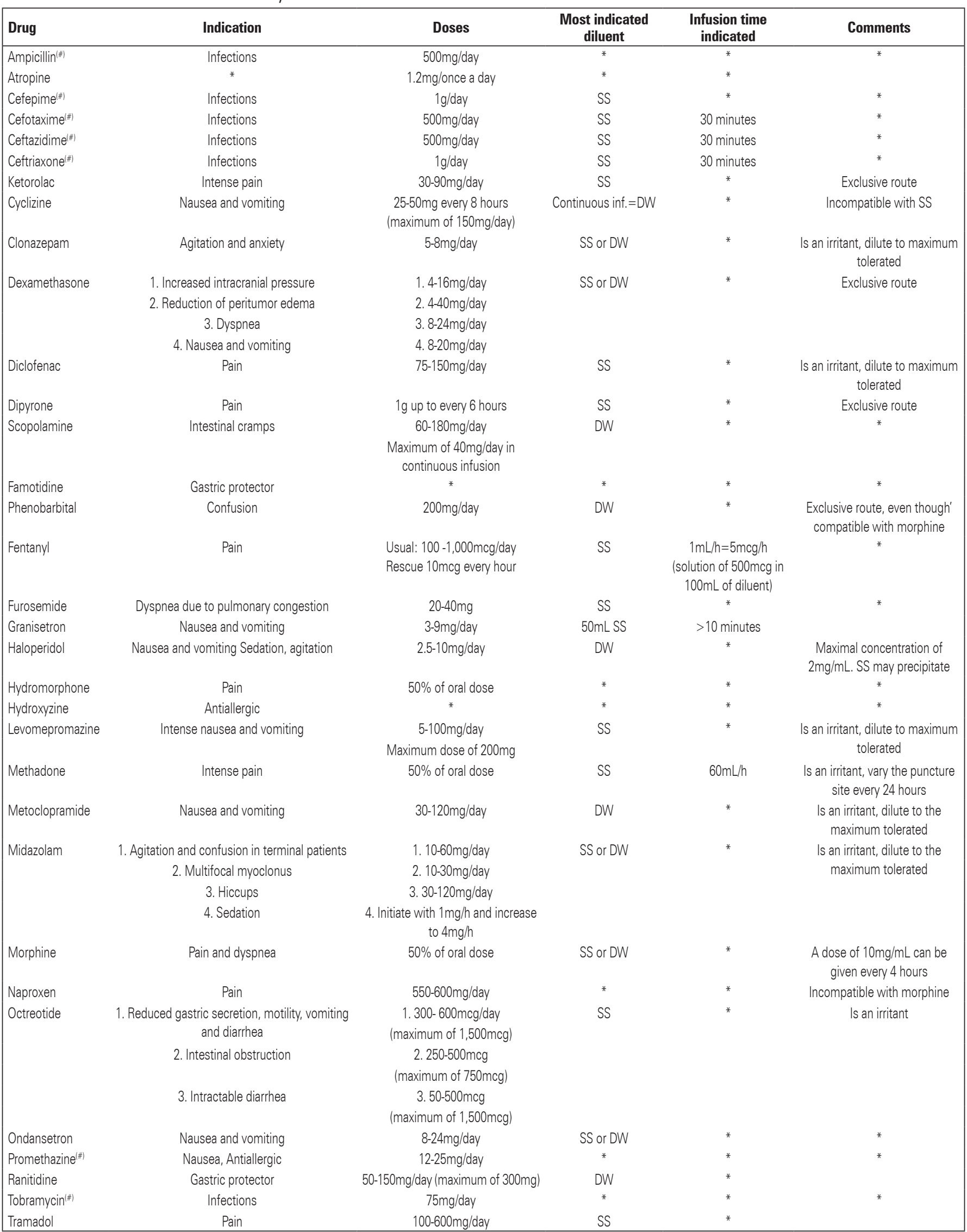

Adapted from: Ferreira KA and Santos AC?

(*) Pereira I. Cuidado paliativo. São Paulo: CREMESP; 2008. Hipodermóclise. p. 260-72. DW: distilled water; SS: saline solution; *: no information available. 


\section{RESULTS}

According to the methodology cited for search of information, 17 pieces of literature (Chart 2) and an electronic database were selected.

The selection of articles resulted in the following findings: five papers covering only information related to the procedure of hydration, i.e., no medications were mentioned, four only focused on the use of medications, and eight presented both types of information. Only five articles cited information related to the form of preparation and administration of the medications.

Of the articles selected, 10 had information related to the advantages and disadvantages of the method, (Chart 3), and only two references did not cite any adverse reactions. ${ }^{(5,13)}$
Most often reported adverse reactions were pain, inflammation at the puncture site, and even edema and tissue necrosis. . $^{3,6,8,12,14,15)}$

In one of the articles located, 57 patients were accompanied at a Prolonged Stay Institution for the Elderly (ILPI, acronym in Portuguese) and received hydration by hypodermoclysis; $88 \%$ of them showed improvement of the general clinical status and $84 \%$ showed improvement in cognitive status after the use of hypodermoclysis. $^{(12)}$

As to information related to medications, very little has been written since few drugs have been studied to date using this route, and few have license for use in subcutaneous infusions. ${ }^{(14)}$ According to one of the articles analyzed, in which an open questionnaire was answered by physicians as to the types of medications most commonly

Chart 2. Literature selected in databases

\begin{tabular}{|c|c|c|c|c|c|c|}
\hline Author & Title & Year & $\begin{array}{l}\text { Medications/ } \\
\text { hydration/both/ } \\
\text { not cited }\end{array}$ & $\begin{array}{l}\text { Advantages } \\
\text { and } \\
\text { disadvantages }\end{array}$ & $\begin{array}{c}\text { Adverse } \\
\text { reactions }\end{array}$ & $\begin{array}{l}\text { Mode of } \\
\text { preparation and } \\
\text { administration } \\
\text { of medications }\end{array}$ \\
\hline Pereira $\left.\right|^{(1)}$ & $\begin{array}{l}\text { Cuidado Paliativo. Conselho Regional de Medicina do } \\
\text { Estado de São Paulo - CREMESP. Hipodermóclise }\end{array}$ & 2008 & Both & Yes & Yes & No \\
\hline Jain $S$ et al. ${ }^{(2)}$ & $\begin{array}{l}\text { Subcutaneous fluid administration - better than the } \\
\text { intravenous approach? }\end{array}$ & 1999 & Both & Yes & Yes & No \\
\hline $\begin{array}{l}\text { Conselho Regional de } \\
\text { Enfermagem de São Paulo }\end{array}$ & Hipodermóclise & 2009 & Both & Yes & Yes & No \\
\hline Takaki CY et al. ${ }^{(4)}$ & $\begin{array}{c}\text { Hipodermóclise: o conhecimento do enfermeiro em } \\
\text { unidade de internação }\end{array}$ & 2010 & Both & Yes & Yes & No \\
\hline Marques C et al.(5) & Terapêutica subcutânea em cuidados paliativos & 2005 & Medications & No & No & No \\
\hline Yap LK et al.(6) & Hypodermoclysis or subcutaneous infusion revisited & 2001 & Hydration & No & Yes & No \\
\hline Ferreira KA et al..$^{(7)}$ & $\begin{array}{l}\text { Hypodermoclysis and administration of medications by } \\
\text { subcutaneous route: A technique from the past with a future }\end{array}$ & 2009 & Both & No & Yes & Yes \\
\hline Griffithis $A^{(8)}$ & $\begin{array}{l}\text { Clinical Guideline for Subcutaneous Infusion (Hypodermoclysis). } \\
\qquad \text { INHS South Gloucestershire }\end{array}$ & 2010 & Hydration & Yes & Yes & No \\
\hline Remington $R$ et al. ${ }^{|9\rangle}$ & $\begin{array}{c}\text { Hypodermoclysis to Treat Dehydration: A } \\
\text { Review of the Evidence }\end{array}$ & 2007 & Hydration & Yes & Yes & No \\
\hline Sasson $\mathrm{M}$ et al. ${ }^{\lfloor 10\rangle}$ & Hypodermoclysis: an alternative infusion technique & 2001 & Hydration & Yes & Yes & No \\
\hline Instituto Nacional do Câncer ${ }^{(11)}$ & $\begin{array}{c}\text { Série Cuidados Paliativos. Terapia Subcutânea no } \\
\text { Câncer Avançado }\end{array}$ & 2009 & Both & Yes & Yes & Yes \\
\hline Arinzon Z, et al. ${ }^{(12)}$ & $\begin{array}{l}\text { Hypodermoclysis (subcutaneous infusion) - effective mode of } \\
\text { treatment of dehydration in long-term care patients }\end{array}$ & 2004 & Hydration & No & Yes & No \\
\hline Frasca D, et al. ${ }^{(13)}$ & $\begin{array}{l}\text { Pharmacokinetics of Ertapenem Following Intravenous } \\
\text { and Subcutaneous Infusions in Patients }\end{array}$ & 2010 & Medications & No & No & Yes \\
\hline $\begin{array}{l}\text { NHS Greater Glasgow and } \\
\text { Clyde }^{(14)}\end{array}$ & $\begin{array}{l}\text { Guideline for the Use of Subcutaneous Medications in } \\
\qquad \text { Palliative* Care for Adults }\end{array}$ & 2010 & Medications & Yes & Yes & No \\
\hline Azevedo EF, et al. ${ }^{(15)}$ & $\begin{array}{l}\text { Administration of antibiotics subcutaneously: } \\
\text { an integrative literature review }\end{array}$ & 2012 & Medications & No & Yes & No \\
\hline Azevedo EF, et al. ${ }^{(16)}$ & $\begin{array}{l}\text { Manual de Cuidados Paliativos. Academia Nacional de Cuidados } \\
\text { Paliativos - ANCP. Hipodermóclise: um método alternativo para } \\
\text { infusão de fluidos e medicações pela via subcutânea }\end{array}$ & 2009 & Both & Yes & Yes & Yes \\
\hline Fonzo-Christe $C$, et al. ${ }^{(17)}$ & $\begin{array}{l}\text { Subcutaneous administration of drugs in the elderly: survey of } \\
\text { practice and systematic literature review }\end{array}$ & 2005 & Both & No & Yes & Yes \\
\hline
\end{tabular}


Chart 3. Advantages and disadvantages of hypodermoclysis ${ }^{(1-4,8-11,14,16)}$

\begin{tabular}{|ll|}
\hline Advantages & Usual infusion time of $1 \mathrm{~mL} / \mathrm{minute}$ \\
\hline Low cost & Only $3,000 \mathrm{~mL}$ over a period of 24 hours may be infused and should be fractioned at different \\
sites & May lead to local edema \\
Easier to obtain new administration sites & Is limited to the administration of electrolytes \\
May be done in homecare/hospice & Nutritional supplements and hypertonic solutions are not indicated \\
Reduction of hospitalizations & Possibility of local reactions \\
Few reports of thrombophlebitis cases & Not indicated in cases of severe dehydration \\
Has not been related to infections and sepsis & In urgency and emergency cases \\
Maybe installed and interrupted easily, opening and closing the infusion system & In cases of severe bacterial infections \\
Has not been associated with clot formation & \\
Does not require complex materials & \\
\hline
\end{tabular}

Chart 4. Compatibility among medications by hypodermoclysis ${ }^{(16,18)}$

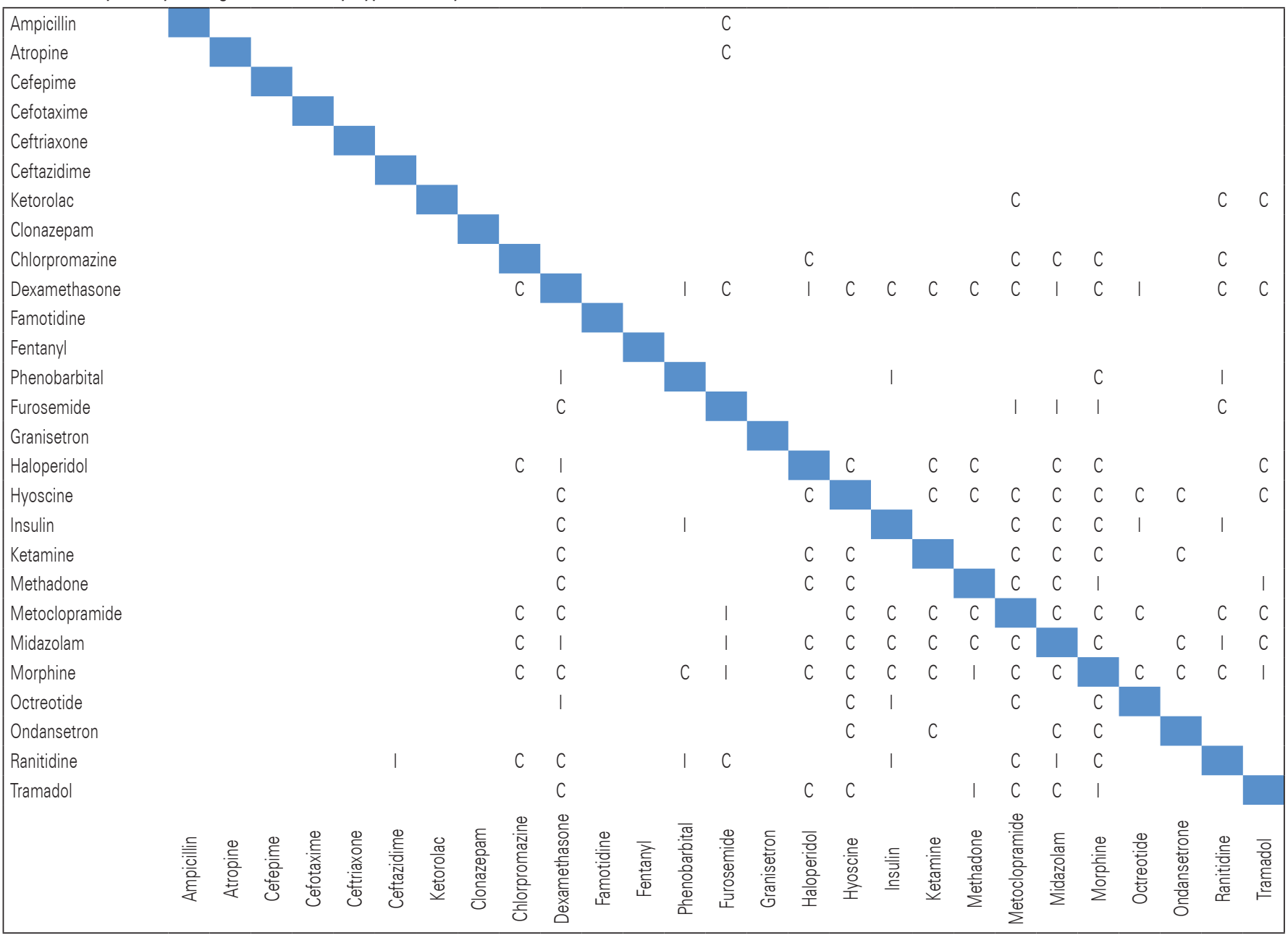

C: compatible; Blank: not tested; l:incompatible.

used, morphine was the most often prescribed drug (98\%), followed by haloperidol (90\%), furosemide (69\%), and metoclopramide (44\%), among others. Still in this article, the physicians were questioned as to the method used to validate the information, and $70 \%$ responded that they prescribed and validated the prescription with other medical colleagues, $32 \%$ validated with the pharmacy service of the hospital, and only $22 \%$ consulted literature. ${ }^{(17)}$ 
Most classes of medications already in use for this route are opioids, antibiotics, antiemetics, and sedatives. Chart 3 shows some information related exclusively to medications that have already been reported in literature regarding use of hypodermoclysis.

In addition to these drugs cited on the table, there are other papers that report the use of other antimicrobials, such as ertapenem, amikacin, gentamicin, and teicoplanin, but these articles still contain limited information and apparently demonstrate equivalence when compared to the usual routes, although the numbers of patients used were very small. ${ }^{(15)}$

A large part of the adverse reactions mentioned in the articles occurred due to inadequate use, such as for example, unsuitable puncture sites, medication inappropriate for that route of administration, inadequate dilution, and lack of rotation of puncture site (change every 96 hours). ${ }^{(11)}$

By means of this research, we noted that the information related to the form of preparation and administration of medications is not yet standardized. Therefore, we must evaluate the patients' conditions before indicating the administration route, and if there are other drugs or even solutions that are already being administered by the subcutaneous route, such as a saline solution, for example. We should also remember that the limit of fluids for infusion over a period of 24 hours cannot surpass $3,000 \mathrm{~mL}$ divided into two different puncture sites $(1,500 \mathrm{~mL}$ at each puncture every 24 hours). ${ }^{(1,2,6,10)}$ This issue may be minimized since one or more drugs may be given by a single infusion system.

Chart 4 presents information related to compatibility among a few medications. ${ }^{(16,18)}$

\section{DISCUSSION}

By means of the results found, we observed that the hypodermoclysis technique is a safe, effective, low cost, and easily applicable methodology ${ }^{(5,12)}$ that seems to bring some benefits. ${ }^{(1-4,8-11,14,16)}$

However, there are still few original studies available on this topic, especially those that include the administration of medications; the working samples located were small, making it difficult to reach a definition as to the efficacy in use of these medications, which also was made evident by a few authors in their studies. ${ }^{(13,15)}$ The original studies used to compose this project focused on issues related to hydration, especially in the elderly. ${ }^{(2,6,9,10,12)}$

Of the medications already indicated and commonly prescribed for the subcutaneous route, as was reported in one of the studies, most are prescribed primarily based on clinical practice more than on literature per se. ${ }^{(17)}$ Additionally, their form of administration ends up being in accordance with its intravenous use, since until now, the most appropriate form for preparation and administration to the patients has not yet been established; however, in literature, there is information that recommends a dilution of $1 \mathrm{~mL}$ of medication to $1 \mathrm{~mL}$ of diluent. ${ }^{(16)}$ Nevertheless, this information is still not a consensus for the use of all the drugs prescribed, as each one of them has their own profile regarding dilution, stability, $\mathrm{pH}$, and these issues may be fundamental in order to avoid adverse events.

If the technique is not applied appropriately, it may cause problems for the patient as described in the results of this article. In this sense, instead of bringing the possible benefits by the technique, it causes more harm.

Of the 17 articles used, only one paper did not cover specific information as to the technique. This one sought to know what the level of knowledge is in a nursing team as to the technique, a fact that called our attention, since many nurses who answered the questionnaire $(71 \%)$ were not familiar with the method..$^{(4)}$ This reinforces the idea that due to scarce availability of information in literature, or availability of repeated information, the technique is not amply made known, and this profile of medical prescription cased great difficulty for the pharmacist and the accompanying team in giving quality orientation so that there is safe management of the techniques of preparation and administration of drugs using the subcutaneous route.

The chart drawn up on the compatibilities shows some possibilities of optimizing puncture sites, as well as volumes of administration, which are capable of providing greater comfort for the patient due to less patient manipulation.

The greatest difficulty in this study was locating information related to the method of preparation and the time of administration of the medications, as was cited in the results, in which only five described some form of preparation and administration of medications. ${ }^{(7,11,13,16,17)}$

The pharmaceutical industry should, on the other hand, invest and prepare studies focused on this administration technique. This can become a distinguishing factor on the market, since such a technique is geared towards patients under Palliative Care and the elderly, as these patients, on the other hand, present with reduced muscle mass, difficulty in puncturing peripheral accesses, and difficulties in swallowing.

New studies could be prepared in a considerable portion of a specific population, in order to also construct 
a safety profile for the patient and for the medication itself.

\section{CONCLUSION}

The complication of this information may direct the pharmacist, as well as the medical and nursing teams in evaluating the medications to be given by hypodermoclysis, in this way offering a guarantee of therapy success and patient safety, besides decreasing risks of adverse events related to administration by such a route.

\section{REFERENCES}

1. Pereira I. Cuidado paliativo. São Paulo: CREMESP; 2008. Hipodermóclise. p. 260-72.

2. Jain S, Mansfield M, Wilcox MH. Subcutaneous fluid administration - better than the intravenous approach? J Hosp Infect.1999;41(4):269-72. Review.

3. Conselho Regional de Enfermagem de São Paulo (COREN-SP). Hipodermóclise. São Paulo: COREN-SP; 2009. p.1-7.

4. Takaki CY, Klein GF. Hipodermoclise: 0 conhecimento do enfermeiro em unidade de internação. ConSientia Saúde. 2010;9(3):486-96.

5. Marques C, Nunes G, Ribeira T, Santos N, Silva R, Teixeira R. Terapêutica subcutânea em cuidados paliativos. Rev Port Clin Geral. 2005;21 (6):563-8.

6. Yap LK, Tan SH, Koo WH. Hypodermoclysis or subcutaneous infusion revisited. Singapore Med J. 2001;42(11):526-9.

7. Ferreira KA, Santos AC. Hipodermóclise e administração de medicamentos por via subcutânea: Uma técnica do passado com futuro. Prática Hosp. 2009;6(65):109-14.

8. Griffithis A. Clinical Guideline for Subcutaneous Infusion (Hypodermoclysis). NHS South Gloucestershire. 2010;1(3);1-13.

9. Remington R, Hultman T. Hypodermoclysis to Treat Dehydration: A Review of the Evidence. J. Am. Geriat. Soc. 2007;55(12):2051- 5.

10. Sasson M, Shvartzman P. Hypodermoclysis: an alternative infusion technique. Am Fam Physician. 2001;64(9):1575-8. Review.

11. Instituto Nacional de Câncer (INCA). Serie Cuidados Paliativos. Terapia Subcutânea no Câncer Avançado. Rio de Janeiro: INCA; 2009. p. 9-27.

12. Arinzon Z, Feldman J, Fidelman Z, Gepstein R, Berner YN. Hypodermoclysis (subcutaneous infusion) affective mode of treatment of dehydration in longterm care patients. Arch Gerontol Geriatr. 2004;38(2):167-73.

13. Frasca D, Marchand S, Petitpas F, Dahyot-Fizelier C, Couet W, Mimoz 0 . Pharmacokinetics of Ertapenem following Intravenous and Subcutaneous Infusions in Patients. Am Soc for Microb. 2010:54(2):924-6.

14. NHS Greater Glasgow and Clyde. Guideline for the Use of Subcutaneous medications in Palliative* Care for Adults. Palliative Care Practice Development Team; 2010; p.7-18.

15. Azevedo EF, Barbosa LA, Cassiani SH. Administration of antibiotics subcutaneously: an integrative literature review. Acta Paul Enferm. 2012;25(5):817-22.

16. Azevedo EF, Barbosa MF. Manual de Cuidados Paliativos. Academia Nacional de Cuidados Paliativos - ANCP. Hipodermóclise: um método alternativo para infusão de fluidos e medicamentos pela via subcutânea. Rio de Janeiro: ANCP; 2009; p. 186-93.

17. Fonzo-Christe C, Vukasovic C, Wasilewki-Rasca AF, Bonnabry P. Subcutaneous administration of drugs in the elderly: survey of practice and systematic literature review. Palliat Med. 2005;19(3):208-19. Review.

18. MICROMEDEX ${ }^{\circledR}$ Healthcare Series. Greenwood Vilage, CO: Thomson Micromedex [Internet] 2011 [cited 2013 Nov 18]. Available from: http://www.thomsonhc. com/micromedex2/librarian/ 